\title{
The Translation of Figurative Languages in Novel Lelaki Harimau by Eka Kurniawan
}

\section{(Penerjemahan Bahasa Kiasan dalam Novel Lelaki Harimau Karya Eka Kurniawan)}

\author{
Nurul Huda Gustema \\ Sufriati Tanjung \\ Linguistik Terapan - Universitas Negeri Yogyakarta \\ Jalan Colombo 1, Karang Malang, Yogyakarta \\ Tel.: +62 (274) 5508836 \\ Surel: nurulhuda.2018@student.uny.ac.id
}

Diterima: 3 Desember 2019 Direvisi: 15 Juli 2020 Disetujui: 22 Juli 2020

\begin{abstract}
Abstrak
Penerjemahan berperan dalam menyediakan akses dari berbagai ilmu pengetahuan dan teknologi terkini, sastra, agama, dan budaya. Novel merupakan salah satu karya sastra yang diterjemahkan ke dalam beberapa bahasa. Dalam sebuah novel, ada beberapa item budaya tertentu, seni, dan bahasa kiasan yang berasal dari bahasa sumber. Penelitian ini bertujuan untuk mengidentifikasi penerjemahanan bahasa kiasan dalam novel Lelaki Harimau karya Eka Kurniawan yang telah diterjemahkan ke dalam bahasa Inggris sebagai Man Tiger oleh Labodalih Sembiring. Dari terjemahan judulnya terungkap bahwa novel tersebut mengandung bahasa kiasan. Oleh karena itu, penelitian ini bertujuan untuk mengidentifikasi strategi dan ideologi yang digunakan dalam menerjemahkan bahasa kiasan yang terdapat dalam novel tersebut. Penelitian ini menerapkan metode deskriptif kualitatif dengan menggunakan teknik baca dan catat. Parameter untuk menentukan kata atau frasa yang termasuk dalam bahasa kiasan digunakan sebagai instrumen. Hasil penelitian juga menunjukkan bahwa strategi yang paling banyak digunakan adalah penerjemahan literal dan domestikasi sebagai ideologi penerjemahan.
\end{abstract}

Kata kunci: bahasa kiasan, Lelaki Harimau, Man Tiger, penerjemahan

\begin{abstract}
Translation plays roles in providing access from various sciences and the latest technology, literature, religion, and culture. Novel is one of literary works that is translated into several languages. In a novel, there are some new culture-specific items, arts, and the figurative language that come from the source language. This research aimed to identify the translation of figurative languages in novel Lelaki Harimau by Eka Kurniawan which had been translated into English as Man Tiger by Labodalih Sembiring. From the translation of the title, it had revealed that the novel contains figurative languages. Therefore, the researcher aimed to examine the strategies and the ideology used in translating the figurative languages contained in the novel. This research implemented decriptive qualitative method, by using reading and note taking technique. A parameter to determine which words or phrases belong to figurative language was used as the instrument. Then, the result showed
\end{abstract}


that the strategy that mostly used was literal translation, and domestication as the translation ideology.

Keywords: figurative language, Lelaki Harimau, Man Tiger, translation

\section{INTRODUCTION}

Translation plays roles in providing access from various sciences and the latest technology, literature, religion, and culture. Translation involves the processes of reproducing the contents of the text in another language (Machali 2009:6). Translation activity starts from the understanding from the smallest unit such as words, phrases, clause, and sentences. Literary work is one of examples of the translation products. In Indonesia, there are around 1.400 publishers which have published 24.000 literary books that have been translated into Indonesian (Siregar 2004). Translation of literary work is not only a transfer of language, but also a process of artistic creation by imitating, capturing the spirit of the original work, defining expressions that correspond to feelings, and conveying the original message clearly without changing the style of the original language. One thing that should be emphasized in translating literary work is the process of translation which contain differences in the linguistic system and culture. In the translation processess, several concepts such as time, space, value, and ideology, can be found in many cultures, but the understanding of those concepts is different from one culture to another (Lewis 2006:12). The translators should determine the prospective reader of the translation and what the translation is for.

Hoed (2006:67) calls it as audience design and needs analysis. Sometimes, translators want to introduce more foreign cultures (foreignization), while the target reader expects the translation must be adapted to its own culture (domestication). The differences from two cultures also cause differences in ideological point of view. If the translators apply inappropriate strategies in translating the figurative languages, there will be some missing informations which cause misunderstandings from the target readers. It is not enough to understand only the meaning of the story contained in the novel, but need to understand the meaning of the language used in it, such as the existence of figurative languages, idiom, or culture-specific items that usually don't have the equivalent meaning in the source language.

There are many theories about translation and, for a translator, the theory on whether he puts the priority on the source language or target language (Newmark 1988:45) is very important. Newmark further explains that if a translator prefers prioritizing the target language, then it is called communicative translation. On the other hand, it is called semantic translation if he puts the priority on the source language. House (1997:112) had first given different names for such understanding. She defines it as covert translation when the source language is concerned since the role of the translator is not visible here and overt translation for the opposite. Venutti in Munday (2001:146) states that 'the translator's invisibility' refers to a translation that emphasizes on target language which is known as domestication; while the opposite is foreignization. Selecting one of these two will bring an impact on the result of the translation. Foreignization is preferred because the translator wants to introduce some terms and cultural values of the source language while domestication is preferred by translators who are more concerned with the target audience of the translated text.

Meanwhile, Vinay dan Darbelnet in Munday (2001:56-58) said that there are two strategies in translating, direct translation and oblique translation. The first technique in direct translation is borrowing, which means words from the source language are used, so that the cultural elements remains. If the direct translation cannot be used, which means the result (1) gives a different meaning, (2) is not meaningful at all, (3) does not correspond to that in the source language, (4) is contextually not natural, and (5) has different language level, then indirect translation can be used 90 
(Munday 2001:57). The techniques in indirect translation are transposition, modulation, equivalence, and adaptation. In transposition, some sentence structure is changed, for example noun in source language becomes verb in target language. By modulation, the content and the sense of the source language are retained but the presentation is changed. It is then adapted to its common use in the target language, such as changing a passive voice or a double negative sentence in the source language becomes an active voice and positive sentence in the target language.

Another theory is proposed by Newmark (1988:103), which proposes other ways to translate, such as by description, reduction, and couplet or triplet. Description means referring something by describing its function while reduction means reducing some information because the meaning is already contained in a certain word or phrase. Couplet means using two techniques at the same time while triplet means using three techniques at the same time. In addition, he explains that some techniques to translate the certain function of languages such as cultural words, idios, or figurative languages are transfer, cultural equivalence, neutralization, component analysis, reduction, and couplet.

The translation problems usually occur in translating a literary work, for example novel (Catford 1986:35). Novel is one form of literary works which has intrinsic and extrinsic elements. In a novel, the author always tries to attract the reader to the images of the reality of life through the stories contained in the novel. Among many novelists who have been existing in Indonesian literary world, in this millennial era, there are some outstanding ones who give great contribution to the development of literature in Indonesia. One of them is Eka Kurniawan, which is called as the new regeneration of Pramoedya Ananta Toer. Some of his novels have been translated into several languages, such as Cantik Itu Luka (2002) which has been translated into 33 languages (Arabic, Bulgarian, Catalan, Chinese, Taiwan, Croatian, Czech, Danish, Dutch, English, Finnish, French, German, Greek, Hebrew, Icelandic, Italian, Japanese, Korean, Lithuanian, Malay, Malayalam, Norwegian, Polish, Portuguese, Romanian, Serbian, Slovak, Slovenian, Spanish, Swedish, Turkish, Vietnamese); Lelaki Harimau (2004) which has been translated into 9 languages (Chinese, English, French, German, Italian, Korean, Norwegian, Polish, Thai); and Seperti Dendam, Rindu Harus Dibayar Tuntas (2014) which has been translated into three languages (English, French, German), In 2016, Lelaki Harimau obtained an award in International Immerging Voices 2016, and make Indonesian literature proud.

Lelaki Harimau is presented as a novel that brings a new thing in the literary world through surrealist stories with narrative styles that lack of dialogues. Overall, Lelaki Harimau contains a sad story of Margio, who has a grudge against his father, Komar Bin Syueb. Margio unconsciously find the figure of a tiger that has been inherited from generation to generation from his grandfather and previous ancestors. Tragically, the tigers always rebelled to kill Komar Bin Syueb, knowing that the owner of the body has a huge revenge on his own biological father. When reading this novel, the readers will be soluble since the novel has very little dialogues. This novel contains many figurative languages, as contained in the title, Lelaki Harimau, which is translated into Man Tiger, instead of translating it into Tiger Man. On the other words, even only from the title, the researcher had found the figurative language that was contained in it. In translating the title, the translator cannot translate it literally since it belongs to figurative languages. Figurative languages are used by the writer to show the feelings indirectly or not using the literal words (Al-Ma'ruf 2009:59). Figurative languages in stylistic researches are idiom, proverbs, and figure of speech. By using figurative languages, the novel will be more interested and attracted. Taylor (1981:167) categorizes figurative languages into 13 (thirteen), such as simile, metaphor, allusion, metonymy, analogy, allegory, synecdoche, personification, symbol, overstatement (hyperbole), understatement, paradox, and irony. Meanwhile, the translation strategies that proposed by Molina and Albir (2002:509), are adaptation, amplification, borrowing, calque, 
compensation, description, discursive creation, established equivalent, generalization, linguistics amplification, linguistics compression, literal translation, modulation, particularization, reduction, substitution, transposition, and variation. Hence, the research problems are: (1) what are the types of figurative language contained in novel Lelaki Harimau by Eka Kurniawan? (2) What are the strategies used in translating figurative languages in novel Lelaki Harimau by Eka Kurniawan? (3) What is the ideology used in translating figurative languages in novel Lelaki Harimau by Eka Kurniawan?

\section{METHOD}

This research implemented descriptive-qualitative method in order to answer the research questions. According to Fraenkel (2016:429), the term qualitative research refers to studies that investigate the quality of relationships, activities, situations, or materials. The source of data in this study were novel Lelaki Harimau written by Eka Kurniawan, which was translated into Man Tiger by Labodalih Sembiring. The data of the research were the translation units of some linguistic forms which were based on particular category, that was, the semantic representations of figurative languages in their various- linguistic forms in novel Lelaki Harimau as the source text and their translations in English as the target text. Translation units were defined by the smallest segments from the source text which were translated individually and separated from other segments as stated by Newmark (1988:54) "as short as is possible, as long as necessary." Therefore, the translation units that were identified in this study are the phrases, clauses, and sentences that contains figurative languages.

Meanwhile, the instrument used in this research was human instrument, who was the researcher herself based on the knowledge that possesed by the researcher (Moleong 2011). Hence, the data of this study will be collected by using note taking technique. According to Sudaryanto (2015:133), note taking techique aims at the classification of the data. The first thing that researcher conducted was the researcher read the novel Lelaki Harimau, and identified the figurative langauges. After that, the researcher compared its translation to English, and identified the strategies and the ideology that were used in translating the novels form the SL (Indonesian) to the TL (English). Therefore, in collecting the data, in order to differentiate which words that belong to figurative languages or not, there were several parameters that indicated which data belonged to figurative languages, as follows: (1) phrases, clauses, or sentences that contains figures of speech, while figures of speech are the particular techniques, (2) phrases or clauses that create imagery, but imagery does not have to use figurative language.

\section{RESULTS AND DISCUSSION}

After reading both Indonesian and English version of the novel, the researcher obtained the data related to several kinds of figurative languages and the translation strategies used in translating them. Therefore, kinds of figurative languages and the strategies used can be seen in the Table 1 and Table 2, as follows:

Table 1. The Frequency of the Figurative Languages

\begin{tabular}{llcc}
\hline & \multicolumn{1}{c}{ Ko } & Frequency & Percentage \\
\hline 1. & Personification & 10 & $43,4 \%$ \\
2. & Hyperbole & 8 & $34,8 \%$ \\
3. & Metonymy & 1 & $4,3 \%$ \\
4. & Simile & 4 & $17 \%$ \\
& & 23 & $100 \%$ \\
\hline
\end{tabular}

Based on the results, it was found that there are four kinds of figurative languages found in the novel, such as personification, metonymy, hyperbole, and simile. Regarding to the Table 1, personification reached the highest percentage. Meanwhile, in translating the figurative languages, there were several strategies which were implemented, as follows: 
Table 2. The Frequency of the Translation Strategies

\begin{tabular}{|c|c|c|c|}
\hline No & Strategis & Frequency & Percentage \\
\hline 1. & Literal translation & 11 & $47,8 \%$ \\
\hline 2. & Adaptation & 6 & $21,7 \%$ \\
\hline 3. & Particularization & 1 & $4,3 \%$ \\
\hline 4. & Generalization & 1 & $4,3 \%$ \\
\hline 5. & Established Equivalent & 1 & $4,3 \%$ \\
\hline \multirow[t]{2}{*}{6.} & Reduction & 5 & $21,7 \%$ \\
\hline & & & 23 \\
\hline
\end{tabular}

\section{Frequency}
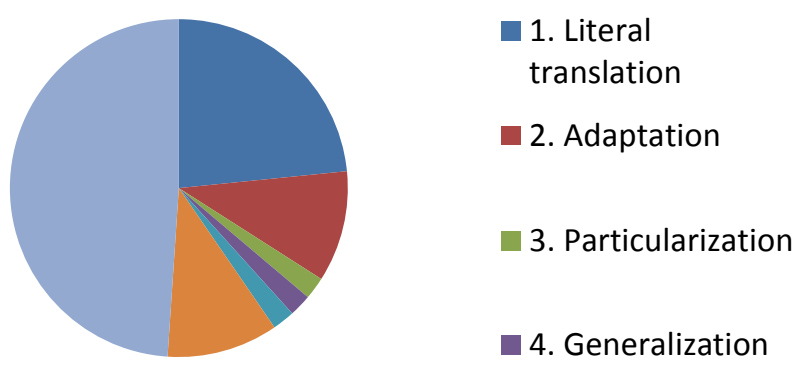

Figure 1. The frequency of Translation Strategies

Based on the results, literal translation reached the highest percentage, with the total number 11 . The results are desribed as follows:

\section{Literal translation}

Data 1 (Chapter 1/Page 1/Line 2)

\begin{tabular}{ccc}
\hline SL & TL & Kind of Figurative Language \\
\hline $\begin{array}{c}\text { Aroma asin yang terbang di } \\
\text { antara batang kelapa }\end{array}$ & $\begin{array}{c}\text { A scent of brine wafted through } \\
\text { the coconut palms }\end{array}$ & Personification \\
\hline
\end{tabular}

In this sentence, it contains an arbitration of living creature to non-living things. The translator implemented literal translation since it did not change the structure of the sentence, and the translated meaning can be accpeted by thetarget readers.

Data 2 (Chapter 1/Page 1/Line 3-4)

\begin{tabular}{ccc}
\hline SL & TL & Kind of Figurative Language \\
\hline $\begin{array}{c}\text { Badai jinak merangkak di } \\
\text { antara ganggang }\end{array}$ & A gentle wind ruffled the algae & Personification \\
\hline
\end{tabular}

In this sentence, it contains an arbitration of living creature to non-living things. The translator implemented literal translation since it did not change the structure of the sentence, and the translated meaning can be accpeted by thetarget readers. However, the translator tried to find the equivalent meaning for the word jinak into gentle.

Data 3 (Chapter 1/Page 2 /Line 22-23)

\begin{tabular}{ccc}
\hline SL & TL & Kind of Figurative Language \\
\hline $\begin{array}{c}\text { Lelaki itu menggiring } \\
\text { motornya dan membunuh } \\
\text { mesinnya. }\end{array}$ & $\begin{array}{c}\text { He swerved on his motorcycle and } \\
\text { killing the engine }\end{array}$ & Hyperbole \\
\hline
\end{tabular}

In this sentence, the word membunuh mesin or killing the engine is considered as hyperbole, since it can be normally said as turn off. Hence, literal translation was implemented in 
translating the sentence, since if the sentence was not translated literally, the sense of the hyperbole would not been felt by the target readers.

Data 4 (Chapter 1/Page 20/Line 17-18)

\begin{tabular}{ccc}
\hline SL & TL & Kind of Figurative Language \\
\hline $\begin{array}{c}\text { Serasa ada air mendidih dalam } \\
\text { lambungnya. }\end{array}$ & $\begin{array}{c}\text { As if her belly were full of boiling } \\
\text { water. }\end{array}$ & Simile \\
\hline
\end{tabular}

Serasa ada air mendidih di lambungnya is a kind of simile which explains that someone is really angry. Hence, literal translation was implemented in order to make the target readers feel its sense.

Data 5 (Chapter 1/Page 22/Line 8)

\begin{tabular}{ccc}
\hline SL & TL & Kind of Figurative Language \\
\hline $\begin{array}{c}\text { Mereka telah mencium bau } \\
\begin{array}{c}\text { amis darah ini dibawa angin } \\
\text { senja ke hidung pemakan } \\
\text { daging mereka. }\end{array}\end{array}$ & $\begin{array}{c}\text { They had caught the smell of } \\
\text { blood on the evening breeze in } \\
\text { their carnivorous snouts. }\end{array}$ & Personification \\
\hline
\end{tabular}

The sentence contains a figurative language, indicated by the sentence bau amis darah dibawa angin, and it was supposed to be translated literally.

Data 6 (Chapter 2/ Page 31/Line 8)

\begin{tabular}{ccc}
\hline SL & TL & Kind of Figurative Language \\
\hline $\begin{array}{c}\text { Seolah Anwar Sadatlah yang } \\
\text { hendak menumpahkan } \\
\text { bencana kepadanya. }\end{array}$ & $\begin{array}{c}\text { As though it was Anwar Sadat } \\
\text { who was going to dish out } \\
\text { trouble. }\end{array}$ & Hyperbole \\
\hline
\end{tabular}

The words menumpahkan bencana in this sentence contains a figurative language hyperbole, and it was translated literally.

Data 7 (Chapter 1/Page 35/Line 7)

\begin{tabular}{ccc}
\hline SL & TL & Kind of Figurative Language \\
\hline Anwar Sadat telah & Anwar Sadat was fluttering his & \\
mengepakkan sayap dan & wings, carried away by & Hyperbole \\
terseret arus badai & unconsciousness. & \\
ketidaksadaran. & & \\
\hline
\end{tabular}

In this sentence, there are two kinds of figurative languages used in translating the figurative language, such as telah mengepakkan sayap and terseret arus badai ketidaksadaran, translated into fluttering his wings and carried away by unconsciousness. In the statement carried away by unconsciousness, the word badai is removed, since in the target language, it is uncommon to be used. Hence, reduction was implemented as the translation strategy.

\begin{tabular}{ccc} 
Data 8 (Chapter 1/Page 56/Line 15) & TL & Kind of Figurative Language \\
\hline SL & Their white & \\
\hline $\begin{array}{c}\text { Harimau putih itu akan } \\
\text { keluar dari tubuh mereka } \\
\text { menyerang musuh. }\end{array}$ & tigresses came out from their & Simile \\
\hline
\end{tabular}

The words harimau putih which was translated into white tigresses was an example of simile, while the writer tried to make it lives in a human's body. The appropriate strategy which was imlemented in order to keep the aesthetic of the language is by translating the words literally. 
Data 9 (Chapter 2/Page 66/Line 8)

\begin{tabular}{ccc}
\hline SL & TL & Kind of Figurative Language \\
\hline $\begin{array}{c}\text { Kepalanya terbenam pada tiga } \\
\text { lapisan bantal lapuk }\end{array}$ & $\begin{array}{c}\text { His head sinking onto three tiers } \\
\text { of rotten pillows }\end{array}$ & Hyperbole \\
\hline
\end{tabular}

Terbenam pada tiga bantal belonged to figurative language, which is hyperbole. Hence, it was translated literally in order to find out the most appropriate equivalency which can be understood and felt by the target readers.

Data 10 (Chapter 3/Page 85/Line 4-5)

\begin{tabular}{ccc}
\hline SL & TL & Kind of Figurative Language \\
\hline $\begin{array}{c}\text { Margio menarik rak piring } \\
\text { yang menjulur dan } \\
\text { membentur pagar rumah- } \\
\text { rumah orang. }\end{array}$ & $\begin{array}{c}\text { Margio had to pull back the plate } \\
\text { rack, which stuck } \\
\text { out and bumped against the } \\
\text { fences. }\end{array}$ & Personification \\
\hline
\end{tabular}

The word membentur which was translated into bump makes the non-living thing is similar with living creature, when it is able to bump the fences.

Data 12 Chapter 1/Page 31/Line 8

\begin{tabular}{ccc}
\hline SL & TL & Kind of Figurative Language \\
\hline $\begin{array}{c}\text { Seolah Anwar Sadatlah yang } \\
\text { hendak menumpahkan } \\
\text { bencana kepadanya. }\end{array}$ & $\begin{array}{c}\text { As though it was Anwar Sadat } \\
\text { who was going to dish out } \\
\text { trouble. }\end{array}$ & Hyperbole \\
\hline
\end{tabular}

The words menumpahkan bencana is categorized as hyperbole. The words were translated literally since it did not change its structure.

\section{Established Equivalent}

Data 12 (Chapter 1/Page 6/Line 11)

\begin{tabular}{ccc}
\hline SL & TL & Kind of Figurative Language \\
\hline $\begin{array}{c}\text { Sungai itu melemparkan } \\
\begin{array}{c}\text { angsa-angsa yang } \\
\text { menghuninya. }\end{array}\end{array}$ & $\begin{array}{c}\text { The creek sweeping hosts of geese } \\
\text { downstream. }\end{array}$ & Personification \\
\hline
\end{tabular}

In this sentence, contains an arbitration of living creature to non-living things.. However, the translator translated the word melemparkan into sweeping, so the translator tried to find the established equivalent of the word.

\section{Adaptation}

Data 13 (Chapter 1/Page 12/Line 5)

\begin{tabular}{ccc}
\hline SL & TL & Kind of Figurative Language \\
\hline $\begin{array}{c}\text { Api yang merayap naik } \\
\text { semakin menambah tampak } \\
\text { sembab wajah ibunya. }\end{array}$ & $\begin{array}{c}\text { And the creeping fire cast a light } \\
\text { on her mother's puffy face, }\end{array}$ & Personification \\
\hline
\end{tabular}

In this sentence, it contains an arbitration of living creature to non-living things. It was indicated by the words api yang merayap which was translated into the creeping fire. However, the word merayap was translated into creeping instead of crawl. Hence, the translator tried to find the equivalent meaning which suitable with the understanding of the target readers, and made the sentence feels like not a translated sentence. 
Data 14 (Chapter 2/Page 86/Line 10)

\begin{tabular}{c|c|c}
\hline SL & TL & Kind of Figurative Language \\
\hline $\begin{array}{c}\text { Waktu itu tentu saja belum } \\
\text { ada mata kucing di wajah } \\
\text { Margio. }\end{array}$ & $\begin{array}{c}\text { Back then she hadn't yet caught } \\
\text { the feline glint in Margio's eyes, }\end{array}$ & Simile \\
\hline
\end{tabular}

In this sentence, the desire to do a bad behaviour is called as mata kucing, and considered as simile. The words mata kucing was translated into feline glint, by using adaptation, in order to find out an equivalent meaning.

Data 15 (Chapter 2/Page 106/Line 9)

\begin{tabular}{c|c|c}
\hline SL & TL & Kind of Figurative Language \\
\hline $\begin{array}{c}\text { Motornya tergolek di batang } \\
\text { kelapa dan mengangkang }\end{array}$ & $\begin{array}{c}\text { His motorbike leant against a } \\
\text { coconut tree, mounted it. }\end{array}$ & Personification \\
\hline
\end{tabular}

There was an arbitration of non-living thing which was considered as a living thing, in the word mengangkang which was translated into mounted in, and the word tergolek into leant. Adapatation strategy was implemented since the word mengangkang is considered as an impolite attitude, and it was adapted into mounted.

Data 16 (Chapter 3/Page 111/Line 3)

\begin{tabular}{ccc}
\hline SL & TL & Kind of Figurative Language \\
\hline $\begin{array}{c}\text { Hampir ambruk pula Margio, } \\
\text { bagai ular boa kekenyangan. }\end{array}$ & Margio was fascinated by his & Simile \\
\hline
\end{tabular}

Bagai ular boa kekenyangan is translated into fascinated by his masterpiece since it has no equivalence in the target language. Hence, adaptation strategy was implemented.

Data 17 (Chapter 3/Page 120/Line 3)

\begin{tabular}{c|c|c}
\hline SL & TL & Kind of Figurative Language \\
\hline Kecemasan itu menguap & People's worries faded away. & Personification \\
\hline
\end{tabular}

In this sentence, the word kecemasan is considered like a living creature which can yawn by itsef. However, the word was translated into faded away, by using adaptation strategy.

Data 18 (Chapter 3/Page 123/Line 4)

\begin{tabular}{ccc}
\hline SL & TL & Kind of Figurative Language \\
\hline $\begin{array}{c}\text { Penyakit itu memorak- } \\
\text { porandakan malam-malam } \\
\text { mereka dengan batuk tanpa } \\
\text { henti. }\end{array}$ & $\begin{array}{c}\text { The disease } \\
\text { ruined their nights with nonstop } \\
\text { coughing. }\end{array}$ & Hyperbole \\
\hline
\end{tabular}

In this sentence, there is a figurative language used, such as hyperbole. It was indicated by the sentence penyakit itu memorak-porandakan. However, it cannot be translated literally, and it was translated by using adaptation into the disease ruined.

Data 19 (Chapter 3/Page 134/Line 13)

\begin{tabular}{c|c|c}
\hline SL & TL & Kind of Figurative Language \\
\hline $\begin{array}{c}\text { Mereka menyeret betina- } \\
\text { betina liar }\end{array}$ & They drag wild women along, & Personification \\
\hline
\end{tabular}

The words betina-betina was translated into women, while betina was commonly used to animals (in bahasa Inndonesia). Hence, the translator used an adaptation as the translation strategy. 


\section{Reduction}

Data 20 (Chapter 1/Page 20/Line 3)

\begin{tabular}{c|c|c}
\hline SL & TL & Kind of Figurative Language \\
\hline $\begin{array}{c}\text { Motor itu bergerak } \\
\text { merangkaki setapak membukit }\end{array}$ & Trailing along the bumpy path & Personifcication \\
\hline
\end{tabular}

This sentence refers to personification since the non-living thing was considered as living creature. However, there were several words that were reduced by translator, or on the other words, he implemented reduction as the translation strategy.

Data 21 (Chapter 2/Page 50/Line 12)

\begin{tabular}{c|c|c}
\hline SL & TL & Kind of Figurative Language \\
\hline $\begin{array}{c}\text { Si gadis masih kecapekan dan } \\
\text { tengah memuntahkan isi } \\
\text { tasnya. }\end{array}$ & $\begin{array}{c}\text { The girl still exhausted and } \\
\text { unpacking. }\end{array}$ & Hyperbole \\
\hline
\end{tabular}

The words memuntahkan isi tasnya which was supposed to be mengeluarkan isi tasnya was categorized into hyperbole. The translator implemented reduction strategy since it just translated into unpacking.

Data 22 (Chapter 3/Page 125/Line 3)

\begin{tabular}{c|c|c}
\hline SL & TL & Kind of Figurative Language \\
\hline $\begin{array}{c}\text { Tak pernah mereka } \\
\text { itu, dan Margan tangan seperti } \\
\text { keberanian perempuan oleh } \\
\text { merampok tangannya. }\end{array}$ & $\begin{array}{c}\text { They had never held hands like } \\
\text { that before, and Margio was } \\
\text { fascinated by the girl's nerve. }\end{array}$ & Hyperbole \\
\hline
\end{tabular}

Perempuan itu merampok tangannya was categorized into hyperbole since the normal word use for the word merampok is memegang or in English is hold. However, the translator also translated the words normally into held hands.

\section{Generalization}

Data 23 (Chapter 2/Page 44/Line 8)

\begin{tabular}{c|c|c}
\hline SL & TL & Kind of Figurative Language \\
\hline $\begin{array}{c}\text { Penyakit itu memorak- } \\
\text { porandakan malam-malam } \\
\text { mereka dengan batuk tanpa } \\
\text { henti. }\end{array}$ & $\begin{array}{c}\text { The disease } \\
\text { ruined their nights with nonstop } \\
\text { coughing }\end{array}$ & Hyperbole \\
\hline
\end{tabular}

In this sentence, the word memorak-porandakan was translated into ruined, while memorakporandakan was categorized as hyperbole in Bahasa Indonesia, and it was generalized by the translator into ruined.

As stated by Catford (1986:35) that translating certain language use is not that easy. Appropriate strategies should be applied in order to make the target readers can enjoy the aesthetic of the languuage, without changing the meaning. Hence, several scholars had revealed several theories related to the translation strategies, such as Vinay dan Darbelnet (2001), Newmark (1988), and Venutti (2001). Also, Hoed (2006:67) revealed the theories about audience design and needs analysis. Sometimes, translators want to introduce more foreign cultures (foreignization), while the target reader expects the translation must be adapted to its own culture (domestication). The differences from two cultures will cause differences in ideological point of view. If the translators apply inappropriate strategies in translating the figurative languages, there will be some missing informations which cause misunderstandings from the target readers. Hence, from the results, it was found that the translator applied domestication as the translation ideology. Meanwhile, for the strategies, the translator implemeted several strategis contained in Newmark (1988) theory, such as 
literal translation, established equivalent, adaptation, generalization, and reduction. Hence, the strategies used by the translator had correlated with the theories revealed by Newmark (1988) and Hoed (2006). In conclusion, the translator had decided the audience design, need analysis, and applied appropriate strategies in order to make the texts feels like not a translated version of the novel. It happens since the choices of the translation strategy is suitable with the target readers, without changing the language style or removing its aesthetics.

\section{CONCLUSION}

In literary translation, The translators should determine the prospective reader of the translation and what the translation is for. Several language uses in literary works such as cultural words, idioms, and ideologies should be translated by using appropriate strategies in order to make the target readers understood with the contents without changing the language style. In addition, the translator is also supposed to be able in deciding the audience design and needs analysis, whether the translators tend to introduce more foreign cultures (foreignization) or adapted to its own culture (domestication). Tthese factors will affect the language variations in translating the text. In conclusion, appropriate strategies and ideology should be implemented in translating a literary work.

\section{REFERENCES}

As-Safi, A. B. 2015. "Toward an Objective Assessment of Literary/Belletrisitric Translation." Translation XV (1).

Baker, Mona. 1992. In Other Words. London and New York: Routledge.

Brasienè, Brigita. 2016. "Literary Translation of Cuture-Specific Items in Lithuanian Translation of Orwell's Down and Out in Paris and London." Kaunas: Vytautas Magnus University.

Cardford, J. C. 1965. A Linguistic Theory of Translation. London: Oxford University Press.

Chasanah, Umi Uswatun 2017. "A Translation Analysis on Ideology of Translation of The Chronicles of Narnia "The Magician Nephew" Written by C. S. Lewis. Kediri: Universitas Dian Nuswantoro.

Fraenkel, Jack R. dan Norman E. Wallen. 2016. How to Design and Evaluate Research in Education. New York: McGraw-Hill Companies.

Handayani, Elisa Indriyani Putri. 2016. "Analisis Kualitas Terjemahan Bahasa Inggris-Bahasa Indonesia dalam Multi Lingual Website.” Surakarta: Universitas Sebelas Maret.

Hoed, B. H. 2006. Penerjemahan dan Kebudayaan. Jakarta: PT Dunia Pustaka Jaya.

Kurniawati, Tri Ningsih. 2016. "Analisis Ideologi Penerjemahan dan Mutu Terjemahan Ungkapan dan Istilah Budaya." Surakarta: Universitas Sebelas Maret.

Larson, M. L. 1984. Meaning-Based Translation: a Guide to Cross-Language Equivalence. Lanham: University Press of America, Inc.

Lewis, R. D. 2006. When Cultures Collide: Leading Across Cultures. London: Nicolas Brealey International. 
Machali, Rochayah. 2015. Pedoman bagi Penerjemah. Bandung: Mizan Media Utama.

Minier, Marta. 2004. "Beyond Foreignisation and Domestication." The AnaChronisT 10:153-174.

Munday, Jeremy. 2016. An Introduction to Translation Studies. Oxford: Oxford University Press.

Nababan, M. Rudolf. 2008. Teori Menerjemah Bahasa Inggris. Yogyakarta: Pustaka Pelajar.

Newmark, Peter. 1988. Approaches to Translation. Shanghai: Shanghai Foreign Language Education Press.

- 1988. A Textbook of Translation. New York and London: Prentice-Hall.

Nord, Christiano. 1965. Translating as Purposeful Activity. New York: Routledge.

Silalahi, Roswita. 2009. "Dampak Teknik, Metode, dan Ideologi Penerjemahan pada Kualitas Terjemahan Teks Medical-Surgical Nursing dalam Bahasa Indonesia." Medan: Universitas Sumatera Utara.

Siregar, R. 2015. "Translation Ideology in the Translation Process of Stephen R.Convey's The 8th Habit Into Indonesian." International Journal of Comparative Literature $\mathcal{E}$ Translation Studies 3 (4):5461.

Suryawinata, Zuchridin dan Sugeng Hariyanto. 2015. Translation: Bahasan Teori dan Penuntun Praktis Menejemahkan. Kanisius: Yogyakarta.

Tanjung, Sufriati. 2018. Penlaian Penerjemahan Jerman-Indonesia. Yogyakarta: Pustaka Pelajar.

Torop, Peeter. 2015. “Translation as Translating as Culture.” Sign Systems Studies 30 (2):593-605.

Venuti, Lawrence. 1995. The Translator's Invisibility: A History of Translation. London and New York: Routledge.

- 2000. The Translation Studies Reader. London and New York: Routledge.

Vid, Natalija (Ed.) 2017. "Use of Domesticated and Foreignized Methods in the Soviet School of Translation." ELOPE: Studies in the English Language and Literature in Slovenia IV (1-2):151-159. 